\title{
Collaborative Strategic Reading (CSR): An Attractive Strategy for Teaching Reading Skill
}

\author{
Dian Novita \\ Fakultas Keguruan dan Ilmu Pendidikan \\ Universitas Muhammadiyah Sidoarjo \\ Sidoarjo, Indonesia \\ diannovita1@umsida.ac.id
}

\begin{abstract}
Reading is the most important activity in any language class. Here, reading is not only as a source of information and a pleasurable doings, but also as a means of consolidating and enhancing one's knowledge of the language. In relation to the teaching of reading for EFL learners, one of the teachers' roles is preparing students with the basic reading skill in order to gain information and knowledge from any reading text. For this, an attractive strategy to build a meaningful learning is needed, especially for non English Department students. The purpose of the study is to describe the students' attitude toward the implementation of Collaborative Strategic Reading (CSR) in the process of reading comprehension learning. In addition, the study is a survey research with opinionnaire as the instrument. The results showed that students gave positive attitude towards the implementation of CSR. Moreover, CSR influenced the students' interest towards English lesson, especially reading successfully. The study is expected to contribute a solution for problems may rise in the English reading class.
\end{abstract}

Keywords—reading comprehension skill; collaborative strategic reading (csr); english for specific purposes (esp)

\section{INTRODUCTION}

In a University level, English for Specific Purposes (ESP) is commonly used as an approach for teaching English for non English Department students. ESP refers to the specific discourse used by professionals and specialists to communicate and transfer information and knowledge [1]. Here, the purpose of English teaching is preparing the students to be able to use English as a language for performing particular work-related functions.

The substance of teaching ESP is not about a special form of language teaching. As a result, it should be based on the principles of effective and efficient learning. For this reason the processes of learning of ESP should not different with learning General English. In addition, there are also four basic skills that should be developed in English learning in ESP, i.e. listening, speaking, reading, and writing.

In relation to ESP perspective, reading ability becomes a fundamental skill for students to recognize scientific texts written in English. In other words, the students' ability in getting the meaning from particular clues in the passage, obtaining the gist of it, and extracting detailed information from the specific reading text is essential.

From the previous description, in teaching ESP reading, teachers are required to provide students with a good reading basis for making them acquire satisfactory skill in technical texts in relation to their selected major of study. Therefore, it is important for ESP educators to develop activities in the process of teaching reading to maintain students' need and interest. Accordingly, in the learning process, language teachers, as the key factor, should motivate students to attend actively in reading class. Moreover, the teacher may offer guidance in helping students to engage in the thinking process [2].

For many foreign language students, processing text is considered as a complex subject. Here, the foreign language readers may get difficulties when they find unknown aspects of the language, such as cohesive devices, lexical cohesion through synonym series, deletion of items in relative pronouns, and so forth [3]. In short, when the students recognize all the language features, they are easier to extract the meaning of a particular text given.

The mastery of vocabulary items becomes another main difficulty that may be faced by English learners in mastering reading skill. In line with this, learners who acquire a great number of vocabulary items may become good readers with a wide range of texts. In more specifically, independent readers recognize about "95 percent" of the words they might find in text for instructional purposes [4].

In addition, there are "98-99 percent" of the words occurring in a particular passage that should be understandable by fluent readers [5]. Frequently, the vocabulary mastery still becomes the students' barrier in processing text. Consequently, the minimum standard of mastery level of reading is hard to be achieved.

The other problem experienced by English learners in common is de-motivating in learning English. This is caused by the absence of feeling that English is important for their field of study. Many of them think that English is a compulsory subject, so that they have to study it to pass the examination. As a result, it is hard for them to enjoy the teaching and learning process.

Motivation is claimed as one of the fundamental aspects in determining language learners' achievement [6]. Here, it 
implies that students would be more successful in learning English if they have high enthusiasm in it.

From English teachers' viewpoint, there have been a number of obstacles met by the teacher in the teaching of ESP reading. Here, one of the problems that the educators may be faced deals with learning strategy. It is expected that English teachers could implement an appropriate strategy, which provides attractive activities. At the end, it will promote students to be more active and accomplish the urge of English for their field of study.

In order to solve the problems mentioned above, the researcher proposes Collaborative Strategic Reading (CSR) as an alternative technique for teaching ESP, especially in reading class. It is believed that CSR is able to help ESP learners have a good learning atmosphere to take part enthusiastically in the classroom activity.

In addition, the technique is also principally effective for students, including language minority students. By applying the phases of CSR in EFL classroom, it helps the students to improve their level of reading proficiency, develop their motivation, enhance social interaction in the classroom, and create a positive learning environment.

CSR is benefit for teachers to train the students for enhancing reading comprehension and building vocabulary, and also working together cooperatively [7]. In other words, the technique is an alternative to facilitate the foreign language learners connect with complex passage and apply the key reading strategies to improve their comprehension. In addition, CSR is an outstanding approach that combines both reciprocal teaching and cooperative learning in instruction [4].

Moreover, CSR is effective for teaching reading in all levels of learners. It also has positive impact on students' achievement in comprehending texts [8].

From the above rationale, the researcher attempts to investigate the students' opinion in ESP learning, especially for reading class of Primary Teacher Education Study Program, Faculty of Teacher Training and Education Universitas Muhammadiyah Sidoarjo using CSR.

\section{Methodology}

Since the present study is to obtain the information of students' attitude on the implementation of CSR in the process of teaching and learning of reading in ESP class, the researcher applies a survey research [9]. Here, there are three kinds of information that can be acquired from survey: factual information, behavioral information, and attitudinal information.

The subjects of the study were the first semester students of Primary Teacher Education Study Program of Faculty of Teacher Training and Education at Universitas Muhammadiyah Sidoarjo, namely class A2. There were 40 students in the class. In a practical sense, the participants of the study were chosen on the basis of the criteria of selecting the samples through the opinionnaire. In addition, in order to avoid the bias of the results of the study, the researcher had limited the participants of the research with the following rules. First, the selected students should be proved to have never been attending private English courses. Second, they had not either got any possibility to live with English native speakers. Here, the researcher used a set of questionnaire to obtain the data for selecting the fitted participants.

With those considerations, there were 20 students who could meet the terms. The next step done by the researcher was obtaining the data of students' learning progress of General English. From this, it was identified that majority of the learners' competence is beginner.

Afterwards, the researcher formulated ten statements including students' attitude towards the implementation of CSR in reading class as individual participant (5 statements) and member of group (5 statements) related to the students' perceptions on CSR in the form of opinionnaire. In addition, there were five options for each statement that can be assessed by using Likert scale: strongly agree, agree, neutral, disagree, and strongly disagree. It was important to identify students' positive or negative attitude towards the strategy [10].

\section{The Implementation of CSR}

In the implementation of CSR, firstly, the teacher gives explicit instruction in strategies, assigns groups roles, and directs for processing text and discussion. In this phase, learners are trained the strategies, namely preview, click-andclunk, get the gist, and wrap-up [7]. The following is the detail of how to teach of the each strategy in CSR.

The first strategy is preview. Here, the teacher asks the students to use all the clues that can be seen in the passage, such as pictures, charts, and graphs, and to look at the headings and subheadings used in the whole text. This strategy is benefit for the learners to give a brainstorming about what they know about the topic and predict what they will learn about the topic. Moreover, previewing helps to stimulate students' interest in the topic and to engage them in active reading from the beginning.

Click-and-clunk is the second strategy used in CSR. It is designed to monitor students' comprehension of the text. Here, it is called "clicks" when students understand the information about what they are reading. On the other hand, when students fail to recognize the meaning of a word, sentence, or paragraph, it is "clunks." Afterward, students work together to identify the clunks with their peers.

The third strategy in CSR is getting the gist. In the strategy, teachers give the knowledge of how to synthesize information and acquire a larger chunk of text. Next, the students are asked to explain it into an idea. Moreover, it is suggested that teachers require the students to state the main of the paragraphs in 10 words or less [11].

"Wrap-up" becomes the last strategy in CSR. The strategy is expected to advance the students' knowledge, understanding, and memory of what they have read. Here, learners learn to create questions and their responses about what they have read and to review the key ideas of the 
material. For this, students are required to create questions that involve higher-level thinking skills [12].

There are four types of questions that can be generated by the students in CSR. The first type is right there questions. It has a specific answer and explicitly stated in the text. Meanwhile, the second one is think and search questions. The responses of these questions also can be found directly from the text. The main difference from the first type is that it may have more than one possible correct answer.

The third type is author and you questions. It demands the learners to read between the lines and use their prior knowledge to make inferences. The last one is on your own questions. Here, the questions constructed connect the students' experiences and feelings on a topic. The answers of the questions may be different among the individuals [13].

For reviewing of what they have read, students formulate the mainly essential ideas of what they have read in their CSR learning logs. Next, they share what they have learned with their classmates. Here, the discussion provides the teacher with valuable information about students' level of understanding.

Students apply those strategies of CSR while working in cooperative learning groups with the support of the teacher. In relation to the cooperative group in CSR, there are six roles that the students can use in discussing of what they have read in the passage, assisting one another in comprehending the text, and providing educational and emotional reinforcement for their friends. The following are the roles in CSR.

The first is leader. His role is leading the group by telling the members what to read next and what strategy to use next. The second role is clunk expert who reminds the group to follow the steps when they try to look for the meaning of a difficult word or concept by using clunk cards. Gist expert is the third one. He directs the group toward the development of a gist, so that the members could state the main idea of the paragraphs.

The next role is announcer. Here, he invites different group members to read or share an idea and monitors all the participants participate in the discussion. In addition, he also makes sure that there is only one person talks at a time. The fifth role in ESP is encourager. He evaluates how well the group has worked together and gives suggestions for improvement. The last role is time keeper; he sets the timer for each portion of CSR.

From those six roles, leader, clunk expert, and gist expert are required. However, the positions of announcer, encourager, and time keeper are able to be combined and done by one student in each group.

For making students become comfortable working with one another, the cooperative learning groups should stay together from 4 to 8 sessions [14]. Moreover, it may give the opportunity for students to form group identity and relationship and learn how to overcome difficulties when they work together [15]. In the study, the researcher appoints the groups for 4 meetings.

\section{FINDINGS AND DISCUSSION}

In the study, the researcher had constructed ten statements of students' attitude towards the CSR implementation in reading class of the first semester students of Primary Teacher Education Study Program of Faculty of Teacher Training and Education at Universitas Muhammadiyah Sidoarjo. The statements cover the students' perception for both as the individual participant and the member of group.

To obtain the data of students' response as the personal participant to CSR in reading class of ESP, the researcher had set the opinionnaire items of $1,2,4,8$, and 9 . In addition, the items of $3,5,6,7$, and 10 had been created to identify the students' perception as the group on CSR implementation. The following table presents the result of the student's attitude after attending the CSR classroom.

TABLE I. The AnAlysis OF Students' AtTitude towards ThE IMPLIMENTATION OF CSR IN READING CLASS

\begin{tabular}{|c|c|c|c|c|c|c|c|c|c|c|c|}
\hline \multirow[t]{2}{*}{ No. } & \multirow[t]{2}{*}{ Statements } & \multicolumn{2}{|c|}{$\mathbf{S A}$} & \multicolumn{2}{|c|}{$\mathbf{A}$} & \multicolumn{2}{|c|}{$\mathbf{N}$} & \multicolumn{2}{|c|}{ D } & \multicolumn{2}{|c|}{ SD } \\
\hline & & $f$ & $\%$ & $f$ & $\%$ & $f$ & $\%$ & $f$ & $\%$ & $f$ & $\%$ \\
\hline 1 & $\begin{array}{l}\text { Reading } \\
\text { class is } \\
\text { more } \\
\text { interesting } \\
\text { to me when } \\
\text { CSR is } \\
\text { implemente } \\
\text { d. }\end{array}$ & 10 & 50 & 8 & 40 & 0 & 0 & 2 & 10 & 0 & 0 \\
\hline 2 & $\begin{array}{l}\text { I enjoy } \\
\text { learning } \\
\text { reading } \\
\text { during the } \\
\text { whole } \\
\text { process of } \\
\text { CSR. }\end{array}$ & 12 & 60 & 6 & 30 & 0 & 0 & 2 & 10 & 0 & 0 \\
\hline 3 & $\begin{array}{l}\text { During the } \\
\text { implementa } \\
\text { tion of } \\
\text { CSR, } \\
\text { students } \\
\text { actively } \\
\text { participate } \\
\text { within a } \\
\text { group. }\end{array}$ & 14 & 70 & 5 & 25 & 0 & 0 & 1 & 5 & 0 & 0 \\
\hline 4 & $\begin{array}{l}\text { CSR makes } \\
\text { me } \\
\text { confident } \\
\text { in reading } \\
\text { class. }\end{array}$ & 16 & 80 & 4 & 20 & 0 & 0 & 0 & 0 & 0 & 0 \\
\hline 5 & $\begin{array}{l}\text { Students } \\
\text { learn how } \\
\text { to respond } \\
\text { actively } \\
\text { when the } \\
\text { others need } \\
\text { help in } \\
\text { completing } \\
\text { the tasks } \\
\text { during the } \\
\text { learning } \\
\text { activity } \\
\text { through } \\
\text { CSR. }\end{array}$ & 12 & 60 & 7 & 35 & 0 & 0 & 1 & 5 & 0 & 0 \\
\hline 6 & Students & 10 & 50 & 9 & 45 & 0 & 0 & 1 & 5 & 0 & 0 \\
\hline
\end{tabular}




\begin{tabular}{|c|c|c|c|c|c|c|c|c|c|c|c|}
\hline \multirow[t]{2}{*}{ No. } & \multirow{2}{*}{ Statements } & \multicolumn{2}{|c|}{ SA } & \multicolumn{2}{|c|}{$\mathbf{A}$} & \multicolumn{2}{|c|}{$\mathbf{N}$} & \multicolumn{2}{|c|}{ D } & \multicolumn{2}{|c|}{ SD } \\
\hline & & $f$ & $\%$ & $f$ & $\%$ & $f$ & $\%$ & $f$ & $\%$ & $f$ & $\%$ \\
\hline & $\begin{array}{l}\text { always } \\
\text { appreciate } \\
\text { one to } \\
\text { another } \\
\text { when they } \\
\text { share their } \\
\text { ideas } \\
\text { during the } \\
\text { learning } \\
\text { activity in } \\
\text { CSR } \\
\text { classroom. }\end{array}$ & & & & & & & & & & \\
\hline 7 & $\begin{array}{l}\text { Students } \\
\text { work } \\
\text { cooperative } \\
\text { ly during } \\
\text { the learning } \\
\text { activity in } \\
\text { CSR } \\
\text { classroom. }\end{array}$ & 12 & 60 & 7 & 35 & 0 & 0 & 1 & 5 & 0 & 0 \\
\hline 8 & $\begin{array}{l}\text { Reading } \\
\text { becomes } \\
\text { easier when } \\
\text { I follow the } \\
\text { steps of } \\
\text { CSR. }\end{array}$ & 15 & 75 & 4 & 20 & 0 & 0 & 1 & 5 & 0 & 0 \\
\hline 9 & $\begin{array}{l}\text { After } \\
\text { attending } \\
\text { the CSR } \\
\text { classroom, } \\
\text { I get better } \\
\text { understandi } \\
\text { ng on } \\
\text { reading } \\
\text { text. }\end{array}$ & 16 & 80 & 3 & 15 & 0 & 0 & 1 & 5 & 0 & 0 \\
\hline 10 & $\begin{array}{l}\text { Students } \\
\text { can take } \\
\text { benefits, } \\
\text { such as } \\
\text { improving } \\
\text { motivation, } \\
\text { self esteem, } \\
\text { and } \\
\text { achieveme } \\
\text { nt after } \\
\text { attending } \\
\text { the CSR } \\
\text { classroom. }\end{array}$ & 14 & 70 & 5 & 25 & 0 & 0 & 1 & 5 & 0 & 0 \\
\hline
\end{tabular}

Note: $\mathrm{SA}=$ Strongly Agree, $\mathrm{A}=$ Agree, $\mathrm{N}=$ Neutral, $\mathrm{D}=$ Disagree, and $\mathrm{SD}=$ Strongly Disagree, $f=$ frequency

Based on the results of the analysis of students's attitude towards the implementation to CSR in reading class of ESP in Table 1, the researcher interprets the data in the following section. First, as individual participant, most of students agreed that reading class was more interesting when CSR was implemented in ESP teaching, especially for reading subject. Here, there were $50 \%$ of the students chose SA and $45 \%$ of the students selected A. In addition, $90 \%$ of the students agreed that they were enthusiatic learning reading during the whole process of CSR. In more detail, there were $60 \%$ of the students answered SA and $30 \%$ of the students voted for A. Moreover, all the students stated that they agreed on the statement of the implementation of CSR makes them feel confident in reading class.
Next, it was also identified that most of students felt easier in learning reading of ESP when they followed the steps of CSR. Specifically, there were $75 \%$ of the students selected SA and $20 \%$ of the students answered A. At last, more than $90 \%$ of students agreed that they got better understanding on reading text after attending CSR classroom. For this statement, there were $80 \%$ of the students stated SA and $15 \%$ of the students answered A.

In relation to group participation, it was about $95 \%$ of the students agreed in the statement that during the implementation of CSR, students actively participate within group. Here, there are $70 \%$ of the students chose SA and $25 \%$ of students selected A as the response. Meanwhile, for the statement "Students learn how to respond actively when the others need help in completing the tasks during the learning activity through CSR," there were $60 \%$ of the students stated SA and $35 \%$ of the students took $\mathrm{A}$ as the answer.

Then, there were a half of the total number of participants of the study $(50 \%)$ pointed SA and $45 \%$ of them chose A for the statement number 6 . In other words, there are $95 \%$ of the students who agreed on the statement "Students always appreciate one to another when they share their ideas during the learning activity in CSR classroom."

Next, there were $60 \%$ of the students stated SA and $35 \%$ of them stated A for the opinionnaire item number 7 . It implied that $95 \%$ of the students agreed that they worked cooperatively during the learning activity in CSR classroom. Finally, for the last statement of the opinionnaire, the students agreed that students could take benefits, such as improving motivation, self esteem, and achievement after attending the CSR classroom. There were $70 \%$ of the students selected SA and $25 \%$ of the students chose A.

From the investigation of the students' attitude towards the implementation of CSR in the reading class of ESP deals with the learners as the personal member and group participant, it can be concluded that most of the students have positive impression.

\section{CONCLUSION}

The study has provided the evidence that students have positive attitude toward the implementation of CSR in reading class of ESP. This can be seen from the findings that most of the participants of the research show their strong agreement towards the usefulness and effectiveness of the use of CSR for teaching reading comprehension in ESP class.

Considering the conclusion above, it is implied that CSR is an attractive strategy to solve the problems in reading class. In the process of learning, this strategy promotes the positive interdependence, interaction among students, individual responsibility, social skills, and personal as well as group evaluation. However, teachers should make sure that all students actively participate in the process of learning. Accordingly, it is important for the participants being well trained before the application of the strategy in order to make them understand each of the job description given. 
There are still plenty of problems and the essences of CSR strategy that need to be uncovered. Therefore, it is expected to see how CSR could be applied in the other language skills, not only for the students of tertiary education but also at the secondary education.

\section{ACKNOWLEDGMENT}

The author would like to thank Universitas Muhammadiyah Sidoarjo for supporting the research.

\section{REFERENCES}

[1] Garrido, Miguel F. Ruiz, Juan C. Palmer-Silveira, and Inmaculada Fortanet-Gomez, "English for Professional and Academic Purposes", New York: Rodopi, 2010.

[2] Brown, Douglas H, "Teaching by principles: An Interactive Approach to Language Pedagogy," New York: Addison Wesley Longman, Inc. 2001.

[3] Hedge, Tricia, "Teaching and Learning in the Language Classroom," Oxford: Oxford University Press, 2000.

[4] Grabe, William, "Reading in a Second Language: Moving from Theory to Practice, "Cambridge: Cambridge University Press, 2009.

[5] Nation, I.S.P., "How Large A Vocabulary Is Needed for Reading and Listening?," in Canadian Modern Language Review, 2006, pp. 59-82.

[6] Dörnyei, Z. "Motivational Factors in the Second Language Attainment: A Review of research in Hungary," in Acta Linguistica Hungraia, 1998, Vol. 44, pp. 261-275.

[7] Klingner, Janette K. and Sharon Vaughn, "Using Collaborative Strategic Reading," in Teaching Exceptional Children Journal, 1998, Vol. 1, pp. 32-37.

[8] Novita, Dian, "The Effectiveness of Collaborative Strategic Reading (CSR) for Teaching Reading Comprehension at Muhammadiyah University of Sidoarjo," in Educate (Jurnal Pendidikan Bahasa dan Sastra), 2012, Vol. 1 (I), pp. 1-12

[9] McKay, S.L, "Researching Second Language Classroom," New Jersey: Lawrence Erlbaum Associates, 2006.

[10] Wright, James D, and Peter V. Marsden, "Handbook of Survey Research $2^{\text {nd }}$ Edition," California: Elsevier, 2009.

[11] Klingner, Janette K., Sharon Vaughn, and Alison Broadman. "Teaching Reading Comprehension to Students with Learning Difficulties," New York: The Guildford Press, 2007.

[12] Raphael, T.E., and K.H. Au, "QAR: Enhancing Comprehension and Test Taking Across Grades and Content Areas," in Reading Teacher Journal, 2005, Vol. 59 (3), pp. 206-221.

[13] Raphael, T.E., "Teaching Question Answer Relationships, Revisited," in Reading Teacher Journal, 1986, Vol. 39 (6), pp. 516-522.

[14] Dishon, D. and O'Leary P.W, "A Guidebook for Cooperative Learning: A Technique for Creating More Effective Schools (Revision Edition)," Florida: Learning Publications, 1993.

[15] Richards, Jack C. and Willy A. Renandya, "Methodology in Language Teaching," Cambridge: Cambridge University Press, 2007. 